$10-2016$

\title{
Book Review: Thieves of State
}

Hugh E. Breakey

Griffith University

Follow this and additional works at: https://digitalcommons.usf.edu/gsp

\section{Recommended Citation}

Breakey, Hugh E. (2016) "Book Review: Thieves of State," Genocide Studies and Prevention: An

International Journal: Vol. 10: Iss. 2: 135-137.

DOI:

http://dx.doi.org/10.5038/1911-9933.10.2.1417

Available at: https://digitalcommons.usf.edu/gsp/vol10/iss2/12

This Book Review is brought to you for free and open access by the Open Access Journals at Digital Commons @ University of South Florida. It has been accepted for inclusion in Genocide Studies and Prevention: An International Journal by an authorized editor of Digital Commons @ University of South Florida. For more information, please contact digitalcommons@usf.edu. 
Book Review: Thieves of State

\author{
Hugh E. Breakey \\ Socio-Legal Centre, Griffith University \\ Brisbane, Queensland, Australia
}

Thieves of State: Why Corruption Threatens Global Security

Sarah Chayes

New York, W. W. Norton \& Company, 2015

245 Pages; Price: \$26.95 Hardcover

Reviewed by Hugh Breakey

Socio-Legal Centre, Griffith University

We underestimate corruption. These three words sum up the driving thesis of Sarah Chayes' Thieves of State. In fact, we-including scholars, commentators and especially Western political and military leaders and advisers - underestimate almost every facet of corruption. We misread its pervasive extent and its networked, systemic nature. We fail to appreciate its crushing impact on those who suffer under its yoke. We downplay the sinister social, political, cultural, and even religious shifts it drives, and the way such dynamics fuel civil strife and armed conflict. And as a result of all of these underestimations, the international community (and the U.S. in particular) make catastrophic strategic miscalculations when engaging with struggling states like Iraq and Afghanistan.

With its brave claims, gripping anecdotes and grim insights into the wheels of power from Kabul to Washington, Thieves of State makes for an engaging read, quite suitable for a lay audience. Despite its popular (footnote-less) format, the book boasts more than enough careful argument to warrant scholarly attention. Chayes' work will be of immediate interest to those who work in corruption or governance studies: a motley array of disciplines including law and constitutionalism, criminology, political science, and economics. But because of the link she draws between endemic corruption and widespread civil strife, her work also will be helpful to scholars of international relations, global security and governance, human rights, and genocide studies.

Rather than dividing corruption into petty and grand types, Thieves of State instead focuses on endemic corruption systems or 'Malign Actor Networks' (136). In such networks, the entire system of government is better understood as a vertically integrated criminal organization: petty bribery and extortion by local public officials is made possible by the higher-level 'grand' political corruption that protects it and profits from it-and vice versa. Money, influence, protection, power and resources course through these inter-locking networks in complex ways, giving rise to a toxic environment where it is integrity and honesty - rather than corruption and chicanery-that become perilous endeavours. "Corrupt and corrupting," as one figure sums up the atmosphere in Nigeria (132).

Chayes leaves her readers in no doubt as to the effect on populations suffering under the authority of these malign networks. While scholars may debate the legal minutiae of understanding endemic corruption as a violation of human rights, the vignettes sprinkled through the book present all-too-perfect expressions of arbitrary interferences with fundamental freedoms, backed up by kleptocratic state power.

Yet Chayes' signature claim lies in what happens next: the population's response to the endemic corruption. She argues that the daily, inescapable indignities of networked corruption strip any vestige of legitimacy from the reigning political regime, and from everyone and everything associated with it. Hardworking, peaceful citizens withdraw their support for the government: "If I see somebody planting an IED," vows an Afghan, outraged at the impunity for police violence when they shook down his brother, "and then I see a police truck coming, I will turn away" (6). But for so many others, resistance takes a more violent, proactive form. Chayes' argument weaves from one conflict-zone to the next, covering Iraq, Afghanistan (Chapters 4, 11), Morocco, Algeria and Tunisia (Chapters 6, 8), Egypt (Chapter 7), Uzbekistan (Chapter 9), and Nigeria (Chapter 10). While the particular organization of the corruption network may differ (as Chayes helpfully models in 
the book's Appendix), in each case she hammers home to the reader the decisive causal role played by corruption and state-sanctioned theft in triggering civil strife and revolt. As much as Western observers might prefer to conceive the population's animus lying in familiar concerns with human rights violations, or democratic deficits, or economic inequality, or religious intolerance, Chayes takes dissidents at their word when they rail against their leaders' corruption and greed. By throwing open the door to all manner of civil strife, corruption threatens global security.

The Arab Spring showed - at least in its beginnings - that such dissident movements may be secular (Chapter 6). Yet Chayes' perhaps most intriguing claim lies in linking endemic corruption and puritanical religious extremism - a link she stresses is by no means constrained to Islamic extremism, or even to modern history. 'Corruption' in every language implies both moral and material depravity - and the purity of religion can often present as the best or only weapon with which to combat it (116). From al Qaeda to Boko Haram, from Protestant rebellions to Nigerian Pentecostal churches, the flagrant corruption of the political elites engenders a puritanical response.

From this basis, Chayes aims to inject concerns with corruption into the thinking and strategizing of all actors in international relations and global security. One key lesson is to avoid seeing civil strife in foreign countries through the short-sighted Western preoccupation with terrorism and religious extremism. Civilians on the ground harbor very different priorities to those of their occupiers or benefactors. Faced with flagrant criminal regimes, populations may well countenance tyrannies or theocracies as the lesser of two evils.

In terms of informing policy, especially in military engagements like Iraq and Afghanistan, Chayes stresses how state corruption works as a force-multiplier for insurgents. In supporting and protecting existing governments, foreign troops become entangled in their extortion, and are viewed by the local population as complicit in the ensuing shake-downs, extortions, land-grabs and theft of national resources. A similar theme holds for diplomatic, development and humanitarian action; shrugging off claims of humanitarian neutrality Chayes avers that in the context of endemic corruption, "economic or even capacity-building support is always political" (198). Ultimately, international actors must be as willing to challenge corruption as they are to call out human rights violations and democratic deficits.

Yet wariness about corruption need not drive a blanket rule to disengage. In her final chapter, Chayes considers a wide array of remedies, including tools in the hands of international leaders, diplomats, business and civil society, that can increase the costs and risks of corruption by developing country governments. While her recommendations here should be required reading for all international actors, Chayes offers less advice about internal efforts to combat domestic state corruption - though her Epilogue rightly reflects on the Global Financial Crisis, showing that systemic corruption networks are not purely a developing world problem.

In terms of evidence and argument, much of the book's persuasive force comes from stories and experience accrued in Chayes' life and research on the ground in these geopolitical hotspots, particularly Afghanistan. Since 2001, Chayes worked as a journalist, ran an NGO, and then was called upon in 2009 to serve as special adviser to ISAF commanders. Her thesis dovetails with the grim recent history of the Middle East, and in particular with the failures of the U.S. to grapple with the problems besetting Iraq and Afghanistan, including its all-too-late realization that corruption fueled the strategic threats of insurgency and extremism.

As well as this hands-on experience, the work is shot through with intriguing scholarly argument and historical evidence. In Chapter Two, Chayes scours the 'mirrors' for 'Princes'; guide-books written by hopeful advisers to their monarchs, spanning from the eight century to the sixteenth, written by Islamic and Christian scholars. Chayes draws one persistently recurring admonition out of this trove: the advice that monarchs shun the theft of their subjects' possessions, lest they drive the population to insurrection. As she observes, even Machiavelli-hardly a political theorist drawn to unnecessary moralizing - upheld this prohibition in The Prince.

Chayes returns to the history twice more. In Chapter Twelve she reflects on the Dutch revolt against absolutist monarchy and its corrupt envoys, which fed into later attempts to create limited government, through John Locke in England and then the founding fathers of the United States. The next chapter moves further back in time, highlighting Luther's challenge as an indictment of the Catholic Church's corruption. The history, Chayes stresses, tells a consistent message. 
Whatever else they may put up with, the masses chafe under flagrant, corrupt, thieving rulewhether temporal or spiritual.

Like any work that hones in on a single causal factor, Chayes' focus on corrupt kleptocracy risks under-emphasizing other triggers driving civil strife - a limitation she explicitly notes (187). So too, more empirically-minded social scientists may wish for further, quantitative evidence to demonstrate the correlation and causation existing between endemic corruption and civil strife. But it would take a stern critic not to be persuaded by Chayes' fundamental thesis that corruption deserves more consideration in conversations about global security.

Several elements of Thieves of State carry relevance for scholars of genocide and atrocity crimes. To be sure, concerns with corruption are not unknown in this context. The United Nations OSAPG's Framework of Analysis for Atrocity Crimes lists corruption as a circumstance that impinges on state's capacity to prevent atrocity crimes. But if Chayes is right about the causative link between kleptocracy and civil strife, then corruption may warrant inclusion as a prime factor placing states under stress and making them vulnerable to social breakdown.

The key question in this context is whether in stripping resistance to insurrections and violent terror, endemic corruption contributes to the wholesale breakdown in social functioning that often characterizes atrocity crimes. While further research on this question beckons, Chayes' work provides some prima facie reasons to think it does.

First, Chayes argues that endemic corruption fuels puritanical religious extremism, with normative ideas about purity seen as an answer to secular government's moral and material depravity. Such extremism can feed into the type of identity politics, and beliefs about the moral impurity of others - both within and outside one's sect-that can foment violent solutions.

Second, kleptocracy gives rise not only to rebellions, but ones who have lost faith in all institutions associated with the rampant corruption. All too often, secular government, economic development, democracy, western-style education, and human rights are tarred with the same brush (115). The rejection of these ideas and institutions may strip societies of vital cultural resources capable of stymieing their collapse into ethnic or religious violence. So too, subsequent international interventions, for example through offices of the United Nations, will be viewed as unwelcome and illegitimate. Cosmopolitan, international and secular actors are seen as complicit in the very problem that drove the insurgency.

Finally, peacekeepers and humanitarians can be important actors in genocide prevention efforts. Yet these groups are routinely forced to work alongside existing governments, supporting and protecting their interests. As such, many of the concerns with complicity Chayes canvassed with respect to U.S. involvement in Iraq and Afghanistan will be relevant here, giving force to recent work on the challenging questions arising between peacekeeping and corruption.

In all, anyone who deals with the conflict-related harms, human rights violations and atrocities that can follow from the wholesale collapse of civic trust will profit from a careful reading of Thieves of State. In conversations and action on works on global security and international affairs, we can no longer afford to underestimate endemic corruption. 